\title{
Hermenéutica de la \\ Educación: Explorar y \\ experienciar la impredictibilidad \\ de la educación (sobre el libro \\ de Andrew Wiercinski)
}

\section{Hermeneutics of Education: Exploring and experiencing the unpredictability of education (about the Andrew Wiercinski's book)}

José Manuel TOURIÑÁN LÓPEZ

Catedrático de Teoría de la Educación

Universidad de Santiago de Compostela.

Facultad de Ciencias de la Educación.

Departamento de Pedagogía y Didáctica

Campus Vida s/n. 15782. Santiago de Compostela.

Web: http://dondestalaeducacion.com/

Researcher ID: L-1032-2014

Orcid: 0000-0002-7553-4483

Correo-e: josemanuel.tourinan@usc.es 


\section{RESUMEN}

El reto de la Pedagogía es transformar la información en conocimiento y el conocimiento en educación. Estamos obligados a definir los rasgos que determinan y cualifican el significado de educación frente a cualquier otra forma de interacción. $Y$ eso quiere decir que llegamos a comprender un objeto complejo. La complejidad de la educación nace de la actividad. Cada educando es agente actor y actor de sus proyectos, la educación tiene carácter axiológico y la educación implica conocimiento y acción a la vez. La hermenéutica aplicada a la educación nos ayuda a comprender la complejidad de la educación. Hay Pedagogía como conocimiento teórico, tecnológico y práctico de la educación y hay Filosofía aplicada a la educación. En este caso, la Hermenéutica de la educación converge con la Pedagogía, como filosofía aplicada a la educación.

\section{ABSTRACT}

The challenge of Pedagogy consists in transforming information into knowledge and knowledge into education. We are required to define the traits that determine and qualify the meaning of education in the face of any other form of interaction. And this means that we come to understand a complex object. The complexity of education stems from the activity. Each educatee is an agent who has to become actor and auctor (author) of their own projects, education has axiological character and education implies knowledge and action at the same time. Hermeneutics applied to education helps us understand the complexity of education. There is Pedagogy as theoretical, technological and practical knowledge of education and there is Philosophy applied to education. In this case, the Hermeneutics of education converges with Pedagogy, as a philosophy applied to education.

\section{PALABRAS CLAVES}

Pedagogía general y aplicada; Educación; Actividad; Hermenéutica de la educación; Pedagogía mesoaxiológica.

\section{KEY WORDS}

General and Applied Pedagogy; Education; Activity; Hermeneutics of Education; Mesoaxiological Pedagogy.

\section{INTRODUCCIÓN}

Construir ámbitos de educación, hacer el diseño educativo derivado y generar la intervención pedagógica correspondiente es competencia general del pedagogo. $\mathrm{Y}$ esa competencia general puede aplicarse a muy diversos ámbitos, familia, escuela, ciudad educadora, cárceles, trabajo, etc. Ese es el futuro de las profesiones de la educación vinculadas a la Pedagogía como conocimiento de la educación. Cualquier programa de formación técnica de pedagogos, ha de tener en cuenta lo que aquí hemos dicho.

La clave de la competencia técnica, en perspectiva pedagógica, estriba en entender y actuar asumiendo que toda la educación depende de nuestra actividad común que debe ser determinada hacia la finalidad educativa. Con esa intención construimos ámbitos de educación e integramos las finalidades dentro de la orientación formativa temporal para la condición humana individual, social, histórica y de especie. Toda la arquitectura curricular está pensada para desarrollar, desde la actividad común y con los elementos estructurales de la intervención, competencias adecuadas, capacidades específicas, disposiciones básicas, conocimientos, destrezas, actitudes y hábitos fundamentales que nos capacitan para ser agentes -actores y autores- de nuestros propios proyectos. 
Esto es así y se fundamenta desde la Pedagogía. El reto de la Pedagogía es transformar la información en conocimiento y el conocimiento en educación. Estamos obligados a definir los rasgos que determinan y cualifican el significado de educación frente a cualquier otra forma de interacción. $Y$ tenemos que lograr avanzar desde el conocimiento a la acción, porque no basta con conocer para actuar. Hay que valorar cada medio utilizado como educativo: esa es la perspectiva mesoaxiológica

Para comprender la perspectiva mesoaxiológica, hay que centrar la reflexión en el significado de educación y su relación con la Pedagogía, que es conocimiento de la educación. Pedagogía mesoaxiológica quiere decir valorar como educativo cualquier medio utilizado para educar; significa hacer conocimiento teórico, tecnológico y práctico de la educación para valorar como educativo cualquier medio que se usa en la intervención pedagógica. Mesoaxiológica quiere decir comprender un medio valorado (en nuestro caso, desde la Pedagogía). La Pedagogía (el conocimiento de la educación) es mesoaxiológica, porque el conocimiento de la educación sirve para valorar como educativo el medio o contenido que se utiliza en el proceso instructivo, ajustándolo a criterios de educación establecidos desde el conocimiento de la educación. Conceptualmente, la perspectiva mesoaxiológica se resume en los siguientes postulados:

1. Conocer, enseñar y educar tienen distinto significado el conocimiento de áreas culturales no es el conocimiento de la educación. El conocimiento de la educación fundamenta el nexo entre mentalidad pedagógica específica mirada pedagógica especializada y acción educativa concreta controlada y programada para formar la condición individual social histórica y de especie de cada educando
2. Transformamos información en conocimiento y conocimiento en educación, ajustándonos al significado de educación, utilizando la actividad común del educando sin la cual es imposible educar y buscando la concordancia entre valores y sentimientos en el paso del conocimiento a la acción

3. La función pedagógica es técnica, no política, aunque la educación sea un asunto de interés político; la decisión en Pedagogía, que es conocimiento de la educación, es tecnoaxiológica y mesoaxiológica

4. En perspectiva mesoaxiológica construimos ámbitos de educación, hacemos el diseño educativo pertinente y generamos la intervención pedagógica, atendiendo a principios de educación y a principios de intervención que se justifican con el conocimiento de la educación

5. Usamos la actividad común de manera controlada para lograr actividad educada y educar la actividad con mentalidad pedagógica específica y mirada pedagógica especializada desde los elementos estructurales de la intervención, porque sin la actividad común es imposible educar y gracias a ella se hace posible que el educando sea agente actor y cada vez mejor agente autor de su propios proyectos $y$ actos.

En este trabajo vamos a reflexionar, desde la perspectiva mesoaxiológica de la Pedagogía, sobre el libro de Hermenéutica de la educación que acaba de publicar el profesor Wiercinski. Hay Pedagogía y hay Filosofía aplicada a la educación. En este caso, la Hermenéutica de la educación converge con la Pedagogía. 


\section{EXPERIENCIAR Y EXPLORAR PARA EJECUTAR MEDIANTE LA ACCIÓN LO COMPRENDIDO E INTERPRETADO, EXPRESÁNDOLO}

Distinguir cualquier otro tipo de influencia e influencias educativas; distinguir influencias de heteroeducación e influencias de autoeducación; distinguir procesos educativos formales, no-formales o informales y educación espontánea; distinguir qué hace educativa a una relación, exige la valoración pedagógica de diversos modos de conducta, atendiendo no solo a criterios de uso y finalidad, sino también a criterios de significado interno al propio concepto y a principios derivados del conocimiento de la educación desde la perspectiva de los elementos estructurales de la intervención pedagógica. En definitiva, hemos de construir el pensamiento que nos permita justificar que la actividad educativa es "educativa", porque: 1) se ajusta a los criterios de uso del término, 2) cumple la finalidad de educar en sus actividades y 3 ) se ajusta al significado real de esa acción, es decir se ajusta a los rasgos de carácter y sentido que le son propios, igual que cualquier otro ente que se defina y sea comprensible (Touriñán, 2014).

Cada modo de significar la educación refleja, individualmente considerado, una posibilidad distinta de abordarla desde la perspectiva del conocimiento pedagógico. Pero, para poder afirmar que algo es realmente educativo y educación, tenemos que preguntarnos (Touriñán, 2016):

- Qué hacemos con todas las actividades para que se conviertan en educación

- Qué hacemos para que una actividad plástica y rítmica sea educativa

- Qué hacemos para que un determinado contenido de área cultural sea transformado de información en conocimiento y de conocimiento en educación
- Qué hacemos para que, en unos casos, enseñemos un área cultural $y$, en otros casos, eduquemos con el área cultural

- Qué hacemos para transformar un área de experiencia cultural en un ámbito de educación

- Qué hacemos para construir un ámbito educativo

Tenemos que avanzar desde discernir, conocer el aspecto, a definir los rasgos propios de educación y a entenderlos en su funcionamiento, porque saber qué es educación es discernir, definir y entender. Todas las educaciones especificadas, si son algo, lo son porque, sustantivamente, son educación y eso quiere decir que tienen en común los rasgos propios que determinan y cualifican una acción como educación y se ejecuta como acción educativa concreta y programada de todos y cada uno de los componentes estructurales de la intervención pedagógica (Touriñán, 2013).

Distinguir cualquier otro tipo de influencia e influencias educativas; distinguir procesos educativos de usos no educativos de los procesos; distinguir relación educativa de la interacción instrumentalizadora de los agentes que nos lleva a coaccionar, manipular, adoctrinar, por hacer referencia a usos instrumentalizadores frecuentes, exige la valoración pedagógica de diversos modos de conducta, atendiendo al criterio de finalidad y de acción en sí misma (Touriñán, 2012).

Si no se hace eso, se simplifica la realidad y se prescribe la reducción o la disyunción frente a la compleja realidad de la acción educativa concreta. Las opiniones, los lemas y las metáforas se convierten en trampas del lenguaje educativo que impiden comprender la complejidad del objeto de conocimiento 'educación', atribuyendo a una estrategia mental (la opinión, el lema o la metáfora sin limitación 
de criterio de significado) el carácter de cualidad de lo real, de manera que, en lugar de desvelar la complejidad, la ciega y la oculta.

Superar la apariencia exige descubrir los rasgos propios de la educación y entenderlos en su funcionamiento. Hay que explicar cada uno de los rasgos de la fisonomía de la cosa definida. Entonces, no solo discernimos una cosa de su apariencia, lo que es de lo que no es, sino que, además, circunscribimos con precisión los límites donde la educación empieza y termina, su perfil unitario, porque saber qué es educación no es solo saber discernir, sino también saber definir y entender el concepto.

$\mathrm{Si}$ somos coherentes con esa forma de ajustarse a criterios de definición, estamos en condiciones de afirmar que, con fundamento en el conocimiento de la educación, los profesionales de la educación no deben convertirse en charlatanes opiniómanos de la Pedagogía, ni en propagandistas de lemas y metáforas, ni en fundamentalistas respecto de su conocimiento, sentido de acción y sentido de vida (Touriñán, 2017).

El profesor Wiercinski ha hecho una reflexión metódica desde la hermenéutica para contribuir a comprender la educación en su significado intrínseco. No usa la hermenéutica como cosmovisión que determina fines de vida deseables que debe cumplir la educación. No usa la hermenéutica como un método que se ajusta como medio a un fin externo dado que se conoce como educación. La hermenéutica, para el autor es, en palabras de Gadamer, una vía de experienciar la acción educativa en su concreta realización:

Hermeneutic philosophy, as I envision it, does not understand itself as an absolute position but as a path of experiencing. Its modesty consists in the fact that for it there is no higher principle than this: holding oneself open to the conversation. This means, however, constantly recognizing in advance the possibility that your partner is right, even recognizing the possible superiority of your partner (Wiercinski, 2019, p. 258).

Education as a mode of life cannot be identified with a philosophy of life, when everything is programmed and controlled. A specifically Ricoeurian hermeneutics of education, which, in fact, can be perceived to be modelled on translation, does not call for a spontaneity that will programmatically end in chaos. However, it does not support a philosophy of life which focuses on predictability, certainty, and stability (Wiercinski, 2019, p. 25).

Hermeneutics of education is, however, not an additional method to be applied in an educational setting. Gadamer reminds us that it was "not my aim to investigate the theoretical foundation of work in [the human sciences] in order to put my findings to practical ends. My real concern was ... not what we do or what we ought to do." As such hermeneutics should not be perceived as a tool, which can be employed to achieve educational goals. Therefore, the hermeneutics of education thematizes predominantly the phenomenon of education as such. It helps us to realize what is happening to us in the process of education. Hermeneutics helps us to understand a noncalculative approach to education. The direct relevance of hermeneutics is in helping us to understand serious misconceptions about education and address some unspoken premises that we often take for granted (Wiercinski, 2019, p. 256).

Para el profesor Wiercinski, la Hermenéutica es por tanto una forma de análisis filosófico que puede aplicarse a la educación sin que esta pierda significado. Más aún, para el autor es la forma de hacer aflorar la educación en todo su esplendor: como acción, como relación, como interacción, como responsabilidad, como 
alteridad, como acogida hospitalaria y empática y como acción moral y ética, en definitiva, como posibilidad de autonomía para definir el sentido de vida (Ortega y Romero, 2019; Touriñán, 2016). En palabras del profesor Wiercinski:

Education is always a collaborative event. Latin collaborare means to labor together (com-laborare). Collaboration brings with itself pain and joy of working together as acting and suffering persons. This joint effort happens in the context of our existential experience and opens up new horizons otherwise unattainable for us as individuals and the community. Education is, therefore, a way of inhabiting the world and as such it reveals its fluid spatial and temporal character. Thus, education is an encouragement to give expression to our being-in-the-world as engaged and inspired persons in our pursuit for self-understanding. Our sensitivity to the new and unexpected calls for constant conscious assimilation of what we consider our own and being mindful of our foremeanings and prejudices. The possibility of a hermeneutic understanding unfolds as the understanding of oneself, oneself as the other, and the others. This understanding happens always in the hermeneutic horizon of responsibility toward oneself and the other. Hermeneutics of education emphasizes transformative character of education: Understanding the other and oneself as the other requires constant revision and alteration of the understanding of oneself. As such, it is the fundamental path to selfformation (Wiercinski, 2019, p.11).

The art of living human life consists in mastering the art of being with oneself and the other. It is the art of facing life. The pivotal task of hermeneutics in disclosing the essence of a human being as an acting and suffering person is, in fact, maximalistic: To assist a person in learning all that is to learn from life and to testify to all that can be testified about the individual and collective human acting and suffering (Wiercinski, 2019, p. 148).

Ese horizonte de responsabilidad es un horizonte ético del yo con el otro en cada situación de interacción. Y solo de esa manera se puede llegar a entender el significado profundo de educar que es siempre proceso de hacer que cada uno se haga dueño de sí mismo y pueda decidir sus conductas y proyectos (Touriñán, 2015).

La riqueza del pensamiento hermenéutico aplicada a la educación está recogida en este libro, tomando como eje de fundamentación lo mejor de los autores-padres de la hermenéutica. La filosofía hermenéutica aplicada a la educación crea una hermenéutica de la educación que nos aproxima a los rasgos que determinan el significado de educar de manera sustantiva (Touriñán, 2018). En palabras del profesor Wiercinski:

Hermeneutics of education calls for an interpretive approach to education. Understanding of the event of education has a clear educational dimension in the life of the human being. Understanding is not just one of the possible behaviors of a person, but the mode of being of Dasein itself. Understanding concerns all our human relations to the world in which we live (Wiercinski, 2019, p. 17).

El mensaje de vida digna, responsable y cívica que se percibe en esta obra es un elemento más a considerar para sumergirse en su lectura. El autor ha construido un pensamiento sobre educación que debe ser puesto a disposición de la comunidad académica para que pueda ser estudiado y analizado con interés filosófico y preocupación por la práctica educativa. No me cabe duda de que, con la lectura de este pensamiento que el profesor Wiercinski nos ha regalado a todos, los profesores encontrarán un 
modo singular y útil de interpretar su tarea de educadores y su compromiso con el ser humano en desarrollo:

Education is the culture of questioning and as such it is an invitation and encouragement to wonder at obvious perplexities of life and to reflect upon human life as a whole. It is not a question of aiming at knowing everything, but rather of facing the future creatively and imaginatively without attempting to domesticate the vision of the future. To aim at a holistic understanding of human life does not mean that we are unrealistic about the impossibility of grasping everything. However, this genuine impossibility is not because we are not good enough to master our understanding of the world, but because we are human beings. As lingual, temporal, historic, and finite beings, we always have a limited perspective. Having this limiting perspective means learning to understand that the only perspective we have is our human perspective, i.e., a limited and finite way of seeing ourselves and the world (Wiercinski, 2019, p. 13).

Responsibility originates from having someone or something entrusted to my care. In this sense responsibility is inseparable from the idea of a mission. There is a task to be accomplished according to the rules. This task goes beyond the interests and the preferences of the acting agent. To be responsible means to be in charge of certain zone of efficacy, where fidelity to one's word given is put to the test. The acting agent is the engaged person, who remains in the activity-passivity relationship with someone or something entrusted to one's care (Wiercinski, 2019, p. 132).

El paso del conocimiento a la acción que se busca en cada relación educativa singular requiere interacción con el educando para que logre la concordancia entre valores y sentimientos, porque ese es el camino pedagógico para lograr que el educando realice algo. Yo puedo elegir hacer algo, puedo comprometerme con ese algo y puedo decidir integrar ese algo como parte de mis proyectos, pero, a continuación, tengo que realizarlo, debo pasar del pensamiento a la acción, debo pasar del valor realizado y realizable a la efectiva realización. $Y$ esto implica interpretación, comprensión y expresión, en la ejecución de la acción. La realización exige ejecutar mediante la acción lo comprendido e interpretado, expresándolo. Y esto se aplica a la acción del educador y a la acción del educando. En palabras del profesor Wiercinski:

To reach understanding means to search for a path that is our own; it is about the courage to take a definite risk. This courage seems to be a necessary condition to get to know oneself and to develop as a person on an ever-growing basis. It is something that differs from a mere spirit of rebellion or pure resistance; it is, rather, this readiness to take a risk, to transform oneself creatively. In this sense, education as an expansion of one's own horizons is transformation. It means awareness and becoming aware that it is worthwhile to work on one's self (Wiercinski, 2019, p. 317).

Education is also a reflection on what, how, and why we can learn. On the educational path, we discover what kind of people we are, as well as what we want to become, or can indeed become. The readiness to take the risk of education is testimony to the recognition of the necessity for transformation, which results from a profound conviction that we do not have some finite vision of ourselves, no matter what moment of life we find ourselves in, as human beings (Wiercinski, 2019, p. 318).

Education does not mean safer, more predictable, and risk-free formal arrangements: Sometimes it is a way of 
finding oneself stranded between promise and hope. This promise applies to a vision of life which everyone entertains differently. And everyone is radically responsible for the development of this vision. No one can take this responsibility from a human being, even where the human being would be very happy to be rid of this incubus. The promise cannot be predicted on the basis of results

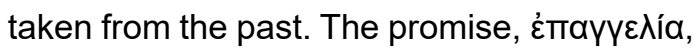
is what reveals itself to us. Its biggest enemy is calculation, spiritual parsimony. And its greatest friends are uncertainty, consent to risk-taking, talent, and determination. The promise of education is not an anticipation of, and a calculation for, future results, but an invitation to courageously clash with life as a task, to look into the future which cannot be determined by our desires and expectations alone.The risk of education is the danger of not noticing the potential that lies in the development as a human being, an inability to imagine the almost unlimited personal possibilities of maturing and growth. Education is not the multiplication and accumulation of the information that gathers momentum around a human being and in its living environment, but constant growth of the human being as a human being (Zuwachs an Sein, an increase in Being).16 The focus on development and growth becomes a way of being that makes education possible. This way of being, despite an apparent weakness, uncertainty, and unpredictability in itself, not only allows a human being to reach his/herself but also represents the chance of opening oneself to the other. The hermeneutics of education, understood in this way, becomes at the same time the hermeneutics of hospitality. It is an invitation to take the risk of education on the chin bravely. In this sense, the risk is not a deficiency (defectum), but a way of discovering life, which is a constant challenge and call issued to all individual persons. Transformation is the main task of education. (Wiercinski, 2019, pp. 320-321).

En última instancia, frente a los que confunden la libertad con los medios, el profesor hermenéutico sabe que los medios sólo tienen un valor condicionado al sujeto libre. Los medios carecen de valor para el sujeto que no se asume como agente actor y autor de sus acciones, comprometiéndose voluntariamente para ordenar su realidad y disponer los medios de acuerdo con ella. En el proceso educativo, al ejecutar la actividad, mejoramos y entrenamos nuestra propia condición humana: sin ella es imposible educar y gracias a ella, con la educación, se hace posible que el educando sea agente actor y cada vez mejor agente autor de su propios proyectos y actos (Touriñán, 2019).

\section{LA COMPLEJIDAD DE LA EDUCACIÓN NACE DE LA ACTIVIDAD COMÚN Y EL SIGNIFICADO DE EDUCACIÓN NACE DE LA CONFLUENCIA DE CRITERIOS DE DEFINICIÓN}

La actividad está presente en toda educación: desde una perspectiva, como principio de intervención $y$, desde otra, como principio de educación. $Y$ precisamente por ser esto así, se explica que la actividad se convierta en el principio-eje vertebrador de la educación y represente el sentido real de la educación como actividad dirigida al uso y construcción de experiencia valiosa para generar actividad educada. Usamos la actividad común para educar, educamos las competencias adecuadas de la actividad común y esperamos obtener actividad educada. En definitiva, usamos la actividad de manera controlada para lograr actividad educada y educar la actividad por medio de las competencias adecuadas (Touriñán, 2019).

El principio de actividad, ni es pasividad, ni es activismo; es uso de la actividad de manera 
controlada para actuar educadamente. Y de este modo, la actividad y el control son principios de la intervención pedagógica, derivados de la condición de agente que tiene que construirse a sí mismo y reconocerse con el otro y lo otro en un entorno cultural diverso de interacción, por medio de los valores que ha de elegir, comprometerse, decidir y realizar, ejecutando por medio de la acción concreta lo comprendido e interpretado de la relación medio-fin, expresándolo, de acuerdo con las oportunidades.

Esto es así, porque, por principio de actividad, nadie se educa sin estar pensando, sintiendo, queriendo, pensando, operando, proyectando y sin estar interpretando símbolos de nuestra cultura creativamente. Nos educamos con la actividad común interna. Pero, además, nos educamos por medio de la actividad común externa, estudiando, jugando, trabajando, indagando-explorando, interviniendo $\mathrm{y}$ relacionándonos con el yo, el otro y lo otro, porque al ejercer una concreta actividad común externa activamos las capacidades comunes internas, las entrenamos, las ejercitamos, las ejercemos y las mejoramos para hacer bien cada actividad común externa. La actividad común externa, por principio de actividad, activa la actividad común interna en cada ejecución concreta de la actividad común externa, sea esta jugar, estudiar, trabajar, indagar, intervenir o relacionar. Al ejecutar la actividad común externa, mejoramos y entrenamos las actividades-capacidades internas: sin la actividad es imposible educar y gracias a ella se hace posible que el educando sea agente actor y cada vez mejor agente autor de su propios proyectos y actos.

El principio de actividad permite afirmar en Pedagogía que la actividad común externa (por ejemplo, jugar) activa la actividad común interna de pensar, sentir, querer, operar, proyectar y relacionar, pero eso no significa caer en el activismo: la actividad por la actividad no educa; pensar de cualquier manera no es educarse, pues educarse, como mínimo, requiere que, al pensar, se mejore el hábito y el modo de pensar.

El significado de educación es confluencia de criterios de definición. Además de la etimología y la sinonimia propias de la definición nominal de un término que nos permiten llegar a definiciones de uso común y a distinguir la actividad por su finalidad, tenemos que llegar con el conocimiento de la educación al carácter y al sentido de la educación, que son los dos elementos que integran el significado desde la perspectiva de la definición real de 'educación'. El carácter determina el significado, el sentido lo cualifica. El concepto clásico de naturaleza de la educación se identifica con el concepto de carácter que yo estoy manejando, pero, en sentido amplio, de modo de ser o actuar de las cosas una vez producidas o nacidas, el concepto de naturaleza de la educación implica el carácter y el sentido, inherentes al significado de "educación", que no se confunde con las materias escolares de estudio derivadas de las áreas culturales consolidadas en cada momento histórico (Touriñán, 2015).

El significado real de educación es confluencia de carácter y sentido. El carácter es el rasgo distintivo o conjunto de características que determinan a algo como lo que es. El carácter de la educación es su determinación, lo que la determina. El carácter nace de la complejidad del objeto 'educación'. La complejidad objetual es la propiedad de la investigación pedagógica que nos hace mantener con realismo la vinculación de la condición humana individual, social, histórica y de especie con el objeto 'educación', y atender a las características propias de este, cuyas relaciones hacen posible identificar sus rasgos internos determinantes (de carácter) y afrontar cada intervención como conocimiento y acción y como vinculación entre valor, elección, obligación, decisión, sentimiento, pensamiento y creación. Las relaciones que se establecen entre esos elementos hacen posible identificar 
los rasgos internos determinantes (de carácter) de la educación. Lo que determina a 'educación' nace de la complejidad objetual de educación y a su vez la complejidad nace de la diversidad de la actividad; intervenimos por medio de la actividad para lograr actividad educada y esto quiere decir que pasamos del conocimiento a la acción para formar la condición humana individual, social, histórica y de especie, atendiendo a las características propias del objeto 'educación', que hacen posible identificar sus rasgos internos determinantes (de carácter). La actividad es el pilar central de la complejidad del objeto 'educación' que exige resolver en cada caso concreto de actuación las relaciones entre valor y elección, obligación, decisión, sentimiento, pensamiento y creación que son propias de la actividad (Touriñán, 2016):

Es posible defender y entender la complejidad del objeto educación atendiendo a tres condiciones que fundamentan los rasgos de carácter de la educación

- La condición fundamentante del valor en la diversidad de la actividad del hombre

- La doble condición de agente actor y autor en cada persona cuando se interviene por medio de la actividad para lograr actividad educada

- La doble condición de conocimiento y acción para la intervención educativa.

El sentido de la educación es lo que la cualifica; es la específica perspectiva de enfoque o cualificación, atendiendo a la vinculación que se establece entre el yo, el otro y lo otro en cada acto educativo.

En el debate pedagógico hablamos de educación intelectual, afectiva, volitiva, operativaintencional, proyectiva-moral y creativa. Hablamos también de educación rítmica, verbal, lingüística, matemática y audiovisual-virtual. Hablamos, además, de educación religiosa, ambiental, científico-natural y socio-histórica. Cada uno de estos tres modos de hablar, refleja en particular un modo distinto de abordar la educación: en el primer caso, hablamos de la pedagogía de las dimensiones generales de intervención; en el segundo caso, hablamos de la pedagogía de las formas de expresión; en el tercer caso, hablamos de la pedagogía de las áreas de experiencia. Las formas de expresión y las áreas de experiencia constituyen ámbitos de educación y son susceptibles de intervención pedagógica. Cada uno de estos ámbitos puede ser desarrollado atendiendo a las dimensiones generales de intervención, desde una determinada perspectiva de orientación o finalidad cualificadora. La educación puede tener sentidos filosóficos diversos: puede ser humanista, localista, globalista, nacionalista, comunitarista, asimilacionista, multiculturalista, interculturalista, intelectualista, relativista, laicista, etcétera. Pero, cuando hablamos del sentido como característica del significado de educación, queremos referirnos a una cualificación propia del significado de educación, vinculada a la relación entre el yo, el otro y lo otro en cada acto educativo, atendiendo a las categorías clasificatorias de espacio, tiempo, género y diferencia específica. Desde esta perspectiva, cualquier acción educativa, sea humanista, socialista, etc., tendrá sentido territorial, duradero, cultural y formativo; tendrá el sentido pedagógico inherente al significado de educación.

Cuando hablamos de sentido pedagógico "cultural", por ejemplo, no estamos hablando de una dimensión general de intervención, ni de uno de los ámbitos de la educación vinculados a formas de expresión y áreas experiencia, ni de uno de los sentidos filosóficos atribuibles a la educación desde la perspectiva de las finalidades. Cuando hablamos de sentido pedagógico "cultural", estamos pensando en un rasgo cualificador, que es propio del significado de educación y que se integra en la orientación 
formativa temporal para la condición humana individual, social, histórica y de especie. Toda educación tiene, por principio de significado, sentido cultural, territorial, duradero y formativo. Hablamos del sentido pedagógico inherente al significado de educación, porque nace de los rasgos que cualifican el significado de educación como relación entre el yo, el otro y lo otro en tanto que interacción en condiciones de espacio, tiempo, género y diferencia específica.

Desde la perspectiva de la definición real, la educación se configura como una tarea y un rendimiento orientado a desarrollar experiencia valiosa y conseguir el uso de las formas de expresión más adecuadas para ella, con objeto de imprimir en la educación, en cada intervención pedagógica, el carácter que determina el significado de educación desde la complejidad objetual propia de la actividad común interna y el sentido que cualifica el significado de la educación, desde la vinculación que se establece entre el yo, el otro y lo otro en cada acto educativo, atendiendo a las categorías conceptuales de espacio, tiempo, género y diferencia específica. Al yo, en tanto que singularidad individualizada, hay que formarlo en todos los rasgos de carácter inherentes al significado de la educación. Al yo, en relación con el otro y lo otro, hay que formarlo en los rasgos de sentido inherentes al significado de educación.

Desde la perspectiva de la definición real, cualquier acto de significado educativo tiene que realizarse ajustándose a las determinaciones y cualificaciones que corresponden al significado real de educación. Toda educación debe ajustarse al carácter y al sentido. La educación matemática, la educación química, la educación física, la educación literaria, la educación artística, la educación moral, la educación ciudadana, etcétera, son educación porque, primariamente, cumplen las condiciones de carácter y sentido propias del significado de "educación". Pero no toda educación tiene que ser matemática, para ser educación. Sustantividad y adjetividad deben ser respetadas en el significado de educación.

Desde la perspectiva de la definición real podemos decir que toda educación tiene que ser personal (que es rasgo de carácter, determinante, y derivado de la complejidad objetual de 'educación'), pero no necesariamente es de matemáticas o de física o de literatura o de artes y, al mismo tiempo, tiene sentido decir que toda educación matemática, física, artística o literaria, atendiendo a la vinculación que se establece entre el yo, el otro y lo otro en cada acto educativo, debe pensarse como educación con sentido territorial, temporal, cultural y formativo.

Desde la perspectiva de la definición real, en cada intervención, se manifiesta el significado de la educación, como confluencia de carácter y sentido, que son los rasgos internos que determinan y cualifican el significado. Pero, además, en cada intervención se manifiesta el conjunto de condiciones derivadas de los criterios de uso y actividad finalista que completan la definición, desde el punto de vista nominal. Así las cosas, el significado de 'educación' exige la confluencia de definición nominal y real, de manera que se ajuste cada actividad a criterios de uso, finalidad y de rasgos de carácter y sentido propios del término ‘educación' (Touriñán, 2015).

\section{CONSIDERACIONES FINALES}

Atendiendo a la definición nominal y real, podemos decir que educar es, en tanto que actividad, una actividad especificada; no es cualquier actividad, si bien cualquier actividad puede ser transformada en una actividad educativa, si conseguimos que cumpla los criterios uso común, de finalidad y de significado real. La actividad educativa, para serlo, requiere el cumplimiento de las condiciones de 
carácter de la educación (axiológico, personal, patrimonial, integral, gnoseológico y espiritual) y las condiciones de sentido de la educación (territorial, duradera, de diversidad cultural y específicamente formativa), así como los criterios de uso y finalidad.

En perspectiva mesoaxiológica, la posibilidad de acción pedagógica es definida: además de enseñar, hay que educar, transformando información en conocimiento y éste, a su vez, en educación. $Y$ hay además un riesgo constante: el conocimiento de la educación fundamenta la decisión pedagógica, que es técnica y de perspectiva mesoaxiológica, pero no es suficiente para garantizar que nadie saltará el limite, politizando la educación, adoctrinando, manipulando o eligiendo en lugar del educando su sentido de acción y su modo de vida.

La hermenéutica profundiza en el sentido filosófico de educar y la complejidad de la educación. La Hermenéutica de la educación converge con la Pedagogía en esta tarea. ¡Que disfruten ustedes de la lectura del libro de filosofía aplicada a la educación, en perspectiva hermenéutica, que ha escrito para todos nosotros el profesor Wiercinski! Se harán una buena idea de cómo se manifiesta la complejidad en la tarea de educar.

\section{REFERENCIAS BIBLIOGRÁFICAS}

Ortega, P. y Romero, E. (2019). A la intemperie. Conversaciones desde la pedagogía de la alteridad. Barcelona: Octaedro.

Touriñán, J. M. (2012). La construcción de ámbitos de educación. Una aproximación a la relación entre áreas de experiencia cultural y educación desde la mirada pedagógica, en Actas del Congreso internacional REDICIS Cultura, educación e innovación. Santiago de Compostela, septiembre,
2012 (publicado en 2014, "Cultura, educación e innovación". Santiago de Compostela: Grupo Correo Gallego, pp. 317-338).

Touriñán, J. M. (2013). ¿Enseñar áreas culturales o educar con las áreas culturales?, en SI(e)TE, Desmitificación y crítica de la educación actual. Barcelona: Octaedro, pp. 57-92.

Touriñán, J. M. (2014). Dónde está la educación. Actividad común interna y elementos estructurales de la intervención. A Coruña: Netbiblo (http:// dondestalaeducacion.com ).

Touriñán, J.M. (2015). Pedagogíamesoaxiológica y concepto de educación. Santiago de Compostela: Andavira (Disponible la $2^{\text {a }}$ edición de 2016).

Touriñán, J. M. (2016). Pedagogía general. Principios de educación y principios de intervención. A Coruña: Bello y Martínez.

Touriñán, J. M. (2017). Mentalidad pedagógica y diseño educativo. De la pedagogía general a las pedagogías aplicadas en la función de educar. Santiago de Compostela: Andavira.

Touriñán, J. M. (2018). Concepto de educación y conocimiento de la educación. The Concept of Education and the Knowledge of Education. ColombiaNueva York: Redipe (Bowker-Books).

Touriñán, J. M. (2019). Estudiar es actividad común externa y siempre educamos con la actividad. Una aproximación desde la perspectiva mesoaxiológica. Teoría de la educación. Revista interuniversitaria, 31 (2), 7-31. 
Wiercinski, A. (2019). Hermeneutics of Education: Exploring and Experiencing the Unpredictability of Education. Zurich: LIT VERLAG, 2019, 332pp. (ISBN 9783-643-91150-6 (pb.) ISBN 978-3-64396150-1 (PDF)

\section{José Manuel TOURIÑÁN LÓPEZ}

Santiago de Compostela

Noviembre de 2019 